Integritas 1.1 (Spring 2013), pp. 1-14.

doi: 10.6017/integritas.v1i1p1

\title{
The Role of Charism and Hospitality in the Academy
}

\begin{abstract}
Aurelie A. Hagstrom
Administrators at Catholic universities can look to ancient Greek, Old Testament, and New Testament sources for thinking about hospitality in the academy today. A theological view of hospitality, modeled after God's own hospitality as manifested in the words and actions of Jesus, offers a model for considering a distinctly Catholic approach to intellectual hospitality. The Dominican charism is one example.
\end{abstract}

\section{Introduction}

It has been twenty-three years since the publication of Ex Corde Ecclesiae by Pope John Paul II. Released in I990, this apostolic constitution gave birth to a movement within Catholic higher education that is still unfolding. Ex Corde challenged the Catholic academy to consider the identity and mission of their colleges and universities in a comprehensive way. In the I990s, the conferences, workshops, seminars, and publications that unpacked the principles and challenges of Ex Corde offered the Catholic academy the opportunity to ponder its origins, evaluate its legacy, and launch new initiatives to strengthen Catholic identity.

Since then, Catholic colleges and universities have spent a tremendous amount of time, energy, and resources to address the issues of mission integration across their campuses. At first, it seemed that the focus was on theology and religious studies departments, asking how they were communicating the faith of the Church to their students. In my experience as a professor of theology, the controversial issue of requesting and receiving a mandatum from the local bishop to teach theology was at the forefront of this first phase in implementing the papal document.

Aurelie A. Hagstrom is an associate professor and chair of the Department of Theology at Providence College. Dr. Hagstrom's work in ecclesiology focuses on the vocation, mission, and spirituality of the laity according to the Second Vatican Council. She is interested in how the laity are the Church in the heart of the world and how they bring the world into the heart of the Church. Recent publications include: The Emerging Laity: Vocation, Mission, and Spirituality (Paulist Press, 2010); as well as articles in Ministry \& Liturgy, Journal of Catholic Higher Education, and Assembly: A Journal of Liturgical Theology. 
The next phase of implementation was when colleges and universities began the arduous, painstaking, and sometimes contentious process of revising their mission statements. These were campus-wide discussions beginning with the board of trustees and moving to the administration, faculty, staff, and student bodies of these schools. As difficult as it was to find the right language, content, and style for a new mission statement, most institutions, it seems to me, found the process clarifying and helpful for all parties involved. By pondering the questions "Who are we?" and "What do we do?", Catholic colleges and universities were able to reclaim their heritage and deepen their commitment to their unique mission.

One component of this mission statement revision initiative was usually the establishment of a new administrative position on campus. The new role of vice president for mission was chartered at many schools as a way to ensure that mission issues would remain central to any administration. If a school was sponsored by a religious order, usually a member of the order was named as vice president for mission. These newly formed offices have had a substantial impact at many institutions as they have forged ties with academics, campus ministry, student life, athletics, and even alumni.

Indeed, these past twenty-three years have given new direction and new impetus to colleges and universities to enhance their Catholic identity and mission while affirming the charisms, ideals, and visions of their founders. But the work is by no means finished. There remain many challenges and obstacles to living out the Catholic mission at these institutions. There are still questions that need to be wrestled with and conditions that need to be addressed in thoughtful ways.

What are some of the questions that still remain open or the conditions that might be changing at our schools? Speaking from my own experience as a faculty member at Providence College, I can articulate a few of them. At Providence College, the changing student population, the hiring of non-Catholic faculty, and dwindling numbers of Dominicans in the classroom pose new challenges to preserving the Catholic, Dominican legacy. It is no longer the case that all of our students come to Providence College precisely because they (and their parents) are seeking a Catholic education. The reasons for student applications are diverse and do not necessarily include any consideration of the institution's Catholic, Dominican mission.

Another reality that has affected our mission is the growing number of non-Catholic faculty being hired. It is no longer possible to simply presuppose that all of our faculty are actively involved in or even interested in our Catholic, Dominican identity. Finally, the aging population of the Dominican Friars on campus means that each year a few more Dominicans retire from active teaching and ministry. These changing conditions call for a renewed creative effort for innovation and adaptation of the mission. Indeed, our attempts to deal with this gradual loss of the Catholic subculture ethos have only just begun. ${ }^{\mathrm{T}}$

See Aurelie A. Hagstrom, "The Dominican Charism and Higher Education: A Personal Reflection from the Field," Journal of Catholic Higher Education 29:1 (2010), pp. 73-82.
A Theological Proposal: Hospitality

As I understand my charge in this Boston College Roundtable, I have been invited, as a theologian, to give a possible theological framework for thinking through some of the ongoing questions of Catholic mission on our campuses. Therefore, I do not intend to lay out a program or compose a list of solutions to the challenges of mission integration. Instead, as my title suggests, I would simply like to propose the biblical theology of hospitality as a foundation for our discussions. Hospitality is fundamentally an expression of and witness to God's grace, since all of us are guests of God's hospitality and are called to embody that hospitality to others in word and deed.

Hospitality is fundamentally an expression of and witness to God's grace, since all of us are guests of

God's hospitality and are called to embody that

hospitality to others in word and deed.

This paper will explore the biblical and theological concept of hospitality in light of the mission of Catholic colleges and universities. The practice of intellectual hos pitality and the Dominican dialogical tradition of theology will also be highlighted. My argument, in short, is that Catholic higher education would do well to appropriate hospitality as a theologically significant moral category. If, at Catholic colleges and universities, the sponsoring religious community is the "host who sets the table," then how can the "guests" be welcomed to Catholic identity, praxis, and worship in the interchange of hospitality?

In this context, hospitality can be understood as the extension of self in order to welcome the "other" by sharing and receiving intellectual and spiritual resources and gifts. As a historic Christian practice, hospitality is distinctively communal and selfgiving, embodying a way of being and thinking about the "other" or the "stranger." It is based in the conviction that when we welcome others, we welcome God, and in welcoming God we are participating in God's reconciling love for the world, manifest in God's Triune nature.

The biblical notion of hospitality has as its starting point the fact that all of us are guests of God's hospitality. The Genesis narratives make it clear that our very existence is pure gift. We exist simply because God wills it. God calls us into existence and sustains us with many wonderful gifts of his creation. The Creator God is a gracious, abundant, and generous host. God has spread out the table of creation before us for our delight-a banquet that was twenty billion years in the making, if the scientists are right. God calls this banquet not only good, but "very good," in Genesis I, and we are welcomed to enjoy its multiple gifts and blessings.

The freedom and dignity of the gift of human life brings with it a moral imperative 
however. The lavish gift of creation and our existence are not idle gifts. The Genesis stories call for companionship, partnership, community, and interpersonal relationships, as symbolized by the man and the woman. Being a guest of God's cosmic hospitality brings with it a call to be hosts, as well, in mediating God's hospitality to others-especially strangers. Our utter dependence on the hospitality of God is itself a motivation to become hosts of God's gifts to others.

\section{Definitions and Etymology}

The complexity and significance of hospitality are revealed in its etymology and history. In the ancient world, hospitality to the stranger was an important aspect of civilization. To lack hospitality was to be barbarian. Hospitality meant not just the provision of material goods, but also a recognition of the humanness and dignity of the other. "Civilization took a decisive turn when the stranger, perceived as enemy, became a guest, one who is entertained at another's house at another's table."2

In ancient Greece, Plato and Homer commented on the important aspect of civilization to be found in hospitality to the stranger. They also alluded to the link, albeit mysterious, between the stranger and the gods. Greek religions attributed the protection of Zeus to strangers. To be inhospitable to a stranger was considered a sacrilege. And in the ancient Near East, the venerable tradition of hospitality suggested a kind of covenant between guests and hosts. Hospitality was considered fundamental to the process of becoming human and a pillar on which all morality rested. Hospitality was perceived as maintaining a kind of inner moral order in the world. ${ }^{3}$

The etymology of the term hospitality reveals an interesting type of ambivalence. In Greek, the words deriving from the xen- stem mean "foreign," or "strange," but also "guest." The ambivalence behind the Greek noun xenos points to the role reversal often found between guests and hosts. It denotes simultaneously a "guest," a "host," and a "stranger." Thus, it illustrates the fluidity of roles of guest and host. ${ }^{4}$ The verb xenizein, or xenizo, means "to surprise" and "to be strange," but also "to entertain" and "to receive as a guest." "The word that the New Testament uses for hospitality is philoxenia. It refers not to a literal love of strangers, but rather a delight in the whole guest-host relationship, with all of its potential for mysterious reversals. The Latin words hospes, meaning "host," and hostis, meaning "enemy," also reflect the intimate connection between strangers, hosts, and guests. The stranger, perceived as an enemy, can become a guest. Hospitality, then, is a way of overcoming the animosity and making the stranger or enemy a friend. As Henri Nouwen states:

This movement allowing us to receive instead of to conquer is the movement from hostility to hospitality. ... To convert hostility into hospitality, to change the

2. Lucien Richard, Living the Hospitality of God (New York: Paulist Press, 2000), p. 5.

3. Christine Pohl, Making Room: Recovering Hospitality as a Christian Tradition (Grand Rapids: Eerdmanns Publishing Company, 1999), p. 5.

4. John Koenig, New Testament Hospitality (Philadelphia: Fortress Press, 1985), p. 8

5. Lucien Richard, p. 6. stranger from hostis to hospes, from enemy to friend, asks for a persistent attempt to create the free space where such a conversion can take place. ${ }^{6}$

\section{Old Testament Tradition of Hospitality}

For the ancient Israelites, part of their identity as the people of God was the responsibility to care for vulnerable strangers in their midst, since they themselves were strangers and sojourners. "Israel's covenant identity includes being a stranger, an alien, a tenant in God's land-both dependent on God for welcome and provision and answerable to God for its own treatment of aliens and strangers." The command to be hospitable to the stranger was grounded in the remembrance of their own status as aliens in the land of Egypt: "The stranger who sojourns with you shall be to you as the native among you, and you shall love him as yourself; for you were strangers in the land of Egypt" (Leviticus I9:34). Or, again, "Love the sojourner therefore; for you were sojourners in the land of Egypt” (Deuteronomy io:I9; see also Exodus 23:9).

As Christine Pohl writes:

Israel's neighbors in the Near East were also typically bound to provide hospitality to the strangers at their door. . . . Such hospitality was recognized as a sacred duty. ... What was distinctive to Israelite society was the explicit legislation regarding the protection of and provision for the resident alien. ${ }^{8}$

When God called Abraham to begin his pilgrimage of faith, he was led away from his father's house and his familiar land to be a stranger in a foreign land (Genesis I2:I). Abraham, himself an alien, was promised numerous descendants who would be sojourners in a land that was not theirs: “. . your descendants will be sojourners in a land that is not theirs, and will be slaves there, and they will be oppressed . . ." (Genesis I5:I3). After the Exodus event and their entrance into the Promised Land, God reminded them that the land belonged to him and that they were still strangers and sojourners (Leviticus 25:23). 9

The Israelites were to reflect the care and concern for strangers and aliens that God himself demonstrated. "He executes justice for the fatherless and the widow, and loves the sojourner, giving him food and clothing” (Deuteronomy I0:I8). Imitating God's vigilant concern for the stranger included allowing the stranger to rest on the Sabbath (Exodus 23:I2; Deuteronomy 5:I4); leaving some sheaves in the field after harvesting to be collected by the aliens (Deuteronomy 24:19-22); and not depriving or abusing the stranger in any way (Exodus 22:2I; Deuteronomy 24:I7-I8, 27:I9). Hospitality to the stranger, then, was a demand of the Israelites' covenantal relationship with God. As Lucien Richard states:

6. Henri Nouwen, "Hospitality," Monastic Studies, Number 10: Easter 1974, pp. 2, 12.

7. Christine Pohl, p. 16

8. Christine Pohl, p. 28

9. See Walter Brueggemann, The Land: Place as Gift, Promise, and Challenge in Biblical Faith (Philadelphia: Fortress Press, 1977), for an extensive treatment of the significance of the relation of the land in Israel's covenant and ethical demands. 
Israel is to care for the stranger because Israel was once a sojourner. Possession of the land, which relieves Israel from the status of sojourner, is only because of God's redeeming grace. Oppression of the stranger, of the poor, is an act against the covenant. ${ }^{10}$

The prophets of ancient Israel called the people back to the stipulations of the covenant by attacking those who disregarded justice and oppressed the vulnerable: ". . . do not oppress the widow, the fatherless, the sojourner, or the poor ..." (Zechariah 7:Io). In fact, the prophets often made fidelity to justice the condition for retention of the land. Injustice and perversions of morality were the sins that would lead to dispossession and exile: “. . . if you do not oppress the alien, the fatherless, or the widow ... then I will let you dwell in this place, in the land that I gave of old ..." (Jeremiah 7:6-7). Israel's response to the outsider, the alien, and the marginalized was a symbol of its response to God himself.

In several Old Testament stories, an encounter with a stranger becomes an occasion of encountering God. These stories contain elements of mystery and surprise because God is often experienced in unexpected ways. The story of the hospitality of Abraham in Genesis I8 is perhaps the most significant. Abraham offers the typical gestures of oriental hospitality to his three mysterious guests: greeting, welcome, foot washing, rest, and a sumptuous meal. In the context of this hospitality, Abraham and Sarah experience a divine encounter. They are told of the future birth of the child of the promise, as well as the impending destruction of Sodom and Gomorrah. However, it is only after their departure that Abraham gradually realizes the identity of his guests. Abraham has hosted God. This narrative links the experience of hospitality to divine presence and blessing.

Other Old Testament characters who provide hospitality and receive God's blessing are the two women who host the prophets Elijah and Elisha. The foreign widow of Zarephath responds to Elijah's request for food, drink, and hospitality even when she and her son are on the verge of death from starvation. For this she is blessed with a supply of flour and oil that does not run out until the drought ends (I Kings I7-I8). In her role as host to the stranger Elijah, she experiences God's blessing, even to the point of having her son raised from the dead by the prophet.

Elisha also experiences hospitality from a woman who provides for his material needs. The wealthy woman of Shunem has a special guestroom constructed for him so that he can stay there whenever he is in that region. Her reward is the promise of a son. As in the story of Elijah, the son later dies, but Elisha restores him to life (II Kings 4:837). The Shunammite woman, then, is yet another example of the connection between hospitality and the reception of blessings. "The biblical stories help us to realize not just that hospitality is an important virtue," writes Henri Nouwen, "but that in the context of hospitality guest and host can reveal their most precious gifts and bring new life to each other."

The Old Testament tradition of hospitality is profoundly rooted in the experience,

10. Lucien Richard, p. 26

11. Henri Nouwen, p. 7 . identity, and covenantal obligations of the People of God. The foundation for the moral imperative of hospitality is their gratitude to God and their utter dependence on him. As Christine Pohl states:

The teachings of the Law, the warnings of punishment for disobedience, and the promise of blessing on obedience reinforce Israelite hospitality toward strangers, as did the individual hospitality stories: guests might be angels, messengers from God, bringing divine promise or provision..$^{12}$

\section{New Testament Tradition of Hospitality}

The New Testament tradition of hospitality is grounded in the ancient Hebrew traditions and yet develops in a completely new way. Because of the Incarnation, God becomes a guest. The Word becomes flesh and literally pitches his tent among us (John I:I4). God enters into the human condition and becomes a stranger among his own (John I:IO-II). The Creator, the cosmic host, becomes a creature, and becomes a guest of the human race. In the New Testament, the heights and depths of human nature are manifested, al within the sacred bonds of hospitality formed among hosts and guests. ${ }^{13}$

In the New Testament, the Greek word xenos can mean stranger or guest or host. So, in the very word, the mutuality that is at the heart of hospitality is revealed. Philoxenia, used in the New Testament for hospitality, is a love of the guest or stranger. It can also mean "the whole atmosphere of hospitality and the whole activity of guesting and hosting," writes Ana Maria Pineda. "Within a philoxenic circle of mutuality, unexpected transformations can occur. ... [T] his circle of mutual hospitality can embrace and transform the people who enter it." ${ }^{14}$

\section{Jesus as the Hospitality of God}

Jesus is portrayed as both guest and host. And it is the combination of these two roles within the person of Jesus that makes the New Testament teachings on hospitality so profound. He is the vulnerable guest who often received no welcome. He depends on hospitality since "the Son of Man has nowhere to lay his head" (Luke 9:58). He is also the gracious host who welcomed the outcast, the sinners, and the marginalized (Luke I5:I-2).

Jesus welcomes and needs welcome; Jesus requires that followers depend on and provide hospitality. The Christian practice of hospitality is always located within the larger picture of Jesus' sacrificial welcome to all who come to him.5

Meal-sharing in fellowship, whether with notorious tax collectors and sinners or with his friends, is a fundamental trait of the ministry of Jesus. Jesus showed himself to be the embodiment of God's hospitality, conveying the good news of God's invitation of salvation to all. The table fellowship of Jesus with "tax collectors and sinners" (Mark

12. Christine Pohl, p. 29

13. John Koenig, p. 2.

14. Ana Maria Pineda, "Hospitality," in Practicing Our Faith, Dorothy C. Bass, ed. (San Francisco: JosseyBass Publishers, 1997), p. 34

15. Christine Pohl, p. 17. 
2:I6) is a concrete manifestation of God's inclusive offer of healing, forgiveness, and reconciliation. As Lucien Richard writes:

To understand what Jesus was doing in eating with sinners, it is important to realize that in the East, even today, to invite a person to a meal is an honor. It is an offer of peace, trust, brotherhood, and forgiveness; in short, sharing a table means sharing a life.... Thus Jesus' meals with the publicans and sinners were not only events on a social level ... but they expressed his mission and message. The inclusion of sinners in the community of salvation, symbolized in table fellowship, is the most meaningful expression of the redeeming love of God. ${ }^{16}$

$$
\begin{gathered}
\text { Jesus, as the definitive expression of God's } \\
\text { hospitality, acts invitationally, depending on } \\
\text { human response and collaboration. }
\end{gathered}
$$

Jesus is the apex of divine hospitality, according to Monika Hellwig. Jesus "acts invitationally, sharing his wisdom with those who are willing to listen and to understand, empowering them by his own initiation of the project of turning human affairs around to face their Creator." ${ }^{17}$ Jesus, as the definitive expression of God's hospitality, acts invitationally, depending on human response and collaboration. If not for the Incarnation, according to Hellwig, "we might never have realized that in the ultimate analysis, the divine hospitality consists of this: that God is self-communicating, self-giving in creation and again in redemption of a creation that was lost unto itself." ${ }^{18}$

Besides his open table fellowship, some of the parables of Jesus also point to the welcome of the Kingdom of God. The parable of the declined banquet invitations in Luke I4:I5-24 sheds light on the future messianic banquet at which the poor, the crippled, the blind, and the lame are invited. The divine hospitality is extended to those who are usually unwanted and excluded. As Brendan Byrne states:

This wonderful parable sheds light on Luke's understanding of the mission of

Jesus and the vision of God it implies. The banquet image accurately conveys what the kingdom of God is all about ... gifting and honoring human beings with the super-abundant hospitality of God. ${ }^{\text {I9 }}$

Jesus' frequent parables about hosting and guesting, his laments at the failure of guests to appear (Matthew 22:2-10), and his dining with poor and rich alike are all revelations of God's hospitality. His attention to food, drink, and hospitality is intended to reveal something profound about the reciprocal relationship between God and humanity.

16. Lucien Richard, p. 66

17. Monika Hellwig, Guests of God: Stewards of Divine Creation (New York: Paulist Press, 1999), p. 117.

18. Monika Hellwig, p. 118.

19. Brendan Byrne, The Hospitality of God (Collegeville, Minn.: Liturgical Press, 2000), p. 124
Jesus intensifies the implications for hospitality when he tells the parable of Matthew 25:3I-46. Those who have welcomed strangers and met the needs of the most vulnerable are welcomed into the Kingdom of God at the final judgment. Jesus identifies himself with the stranger, the naked, the thirsty, the hungry, the imprisoned, and the sick. Entrance into the Kingdom is connected to the practice of Christian hospitality in this life. The parable presents a reversal of roles: Jesus is identified with the stranger and Christians are called to be the hosts. When the needs of the vulnerable are met, it is actually God who is welcomed. The face of the stranger, writes Ana Maria Pineda, is the face of Christ. "When it is most fully realized, hospitality not only welcomes strangers it also recognizes their holiness." "2o "This Gospel text," writes Pope John Paul II, "is not a simple invitation to charity: it is a page of Christology which sheds a ray of light on the mystery of Christ." ${ }^{21}$ Jesus himself wishes to be identified with the poor, the needy, and the stranger.

\section{Hospitality and the Mission of the Church}

In addition to the Gospel teachings of Jesus, the New Testament contains exhortations to hospitality in the other writings. In Paul's teaching, for example, he exhorts the Corinthians and the Romans to be inclusive at Church meals (I Corinthians II:I7-34; Romans I4:I-I5:7). In Galatians 2:II-I4, Paul relates his firm stand on the practice of shared table fellowship among Gentile Christians and Jewish Christians in the Church at Antioch. He advises the Christians at Rome to "Contribute to the needs of the saints, practice hospitality" (I2:I3). Here hospitality becomes the means of meeting the needs of other Christians and creating a partnership in the Gospel. The Romans are to "welcome one another" as Christ had welcomed them (I5:7). Hospitality is even a qualification for leadership in the early Christian communities (I Timothy 3:2; Titus i:8).

It seems that the practice of hospitality was vital to the mission of the early Church Welcoming traveling missionaries and responding to their material needs were the responsibilities of believers. As I Peter 4:9 urges, "Practice hospitality ungrudgingly to one another." The fellowship or partnership that this hospitality created is alluded to in Paul's Letter to the Philippians, where he states that they share a partnership in his mission because of their hospitality toward him (I:5). Abraham Malherbe observes that an entire vocabulary developed in the early Church to describe the hospitable reception and sending forth of traveling missionaries who were spreading the faith..$^{22}$ Hospitality, the mutual giving and receiving, is a catalyst for the fruitfulness of mission. In the simple human gestures of invitation, welcome, and provision, the redeeming work of God is revealed.

20. Ana Maria Pineda, p. 34

21. Pope John Paul II, Novo Millennio Ineunte, Apostolic Letter, January 6, 2001, Section \#49.

22. Abraham Malherbe, Social Aspects of Early Christianity, 2nd edition (Philadelphia: Fortress Press, 1983), p. 96. Among the passages he cites are Romans 16:2; I Corinthians 16:6,11; and Titus 3:13 See his chapter "House Churches and Their Problems," pp. 60-91. See also J. H. Elliott's A Home for the Homeless: A Sociological Exegesis of I Peter (Philadelphia: Fortress Press, 1981) for the connection between mission and hospitality. 
The Letter to the Hebrews warns against neglecting hospitality: "Do not neglect to show hospitality to strangers, for thereby some have entertained angels unawares" (13:2). In this reference to the experience of Abraham in Genesis I8, the author of Hebrews is presenting the experience of hospitality as the sacred space of divine encounter. This divine encounter is transformative. According to Parker Palmer, "Through the stranger, our view of self, of world, of God, is deepened and expanded. Through the stranger, we are given a chance to find ourselves. And through the stranger, God finds us." ${ }^{23}$

The divine encounter of the two disciples on the road to Emmaus is the most poignant account of table fellowship as transformation, reconciliation, and renewal (Luke 24:I3-35). It is in offering hospitality to the stranger, Jesus, that the two disciples come to experience God and recognize the risen Lord. Jesus, who is invited as guest, becomes host as he breaks the bread as an act of self-disclosure. The reversal of roles opens the way for a revelation in the context of a shared meal.

But once more the guest becomes host. In a way clearly meant to recall the institution of the Eucharist at the final supper (22:19-20; also the multiplication of the loaves and fishes 9:I6), Jesus breaks bread, blesses it, and gives it to them (v.30). He, who is receiving their hospitality, provides for them the hospitality of God. ${ }^{24}$

\section{Eucharist and the Hospitality of God}

By far the most profound experience of the hospitality of God in the New Testament is in the Eucharist. God, as host, also becomes the food and drink at the table. During the Passover meal of the Last Supper, Jesus invites the disciples to share in the bread and wine which point toward his impending sacrificial death. His body will be broken and his blood will be shed (Mark I4:22-25; Matthew 26:26-29; Luke 22:15-20). Jesus draws them into the paschal mystery in the context of this table fellowship, where he is both the host and the meal itself.

The Eucharist is the most fundamental experience of the hospitality of God because it anticipates and reveals the future messianic banquet of heaven (Luke 22:I6, 30). The Church celebrates in the Eucharist not only the hospitality of God experienced here and now, but also the foretaste and pledge of the future, eschatological hospitality of the Kingdom. The Eucharist is the anticipation of the everlasting hospitality in the fullness of the Kingdom. As Eugene LaVerdiere relates:

Jesus, his disciples, all who would follow later, and the church itself are a people . . . of hospitality, both offered and received. The Eucharist is the supreme expression of that hospitality, sustaining them on their journey to the kingdom of God. ${ }^{25}$

23. Parker Palmer, The Company of Strangers: Christianity and the Renewal of America's Public Life (New York: Crossroad, 1981), p. 69.

24. Brendan Byrne, p. 189.

25. Eugene LaVerdiere, Dining in the Kingdom of God (Chicago: Liturgical Training Publications, 1994), p. 9 .
Sharing in the Eucharist invites and empowers Christians to extend the hospitality of God to others. Being a guest of God in the Eucharist brings with it a responsibility to become hosts to others. Monika Hellwig writes that the Eucharist is "in the first place the celebration of the hospitality of God shared by guests who commit themselves to become fellow hosts with God." ${ }^{26}$ Those who participate in the Eucharistic feast become mediators of God's abundant hospitality. The practice of hospitality becomes, for the Christian community, "a way of being the sacrament of God's love in the world." ${ }^{27}$

\section{Intellectual Hospitality and Dominican Charism}

Drawing upon this rich biblical theology of hospitality, how might we apply its principles to the academic life? Is it possible to think of the classroom as a place of hospitality? Might the professor act as host and welcome the students as guests? And in this interchange of hospitality, might there be, at times, a surprising reversal of roles wherein the professor becomes guest?

Intellectual hospitality involves welcoming others through openness in both sharing and receiving claims to knowledge and insight. . . . [I]t is marked by awareness that ... the perspective of the other could easily supplement and perhaps correct one's own work or even transform one's self-understanding. ${ }^{28}$

This sort of confidence in seeking the truth wherever it may be found is based upon the conviction that truth is one, and that there can be no contradiction between the truth that flows from faith and that which comes through reason.

As stated earlier, I am on the theology faculty at Providence College, a liberal arts college founded by Dominican Friars in I9I7. And so, I would like to propose the Dominican tradition of theology as one concrete example of intellectual hospitality. The Dominican approach to theology is dialogical and includes a certain kind of "intellectual hospitality," modeled by St. Dominic himself.29

While traveling through Toulouse, St. Dominic encountered an innkeeper who was a member of the Albigensian heretical sect. St. Dominic stayed up all night sitting with him and talking about the truths of the Catholic faith. By dawn, we are told, St. Dominic had won the innkeeper back to the true faith. This famous incident illustrates that the

26. Monika Hellwig, The Eucharist (Kansas City, Mo.: Sheed and Ward, 1992), p. 18.

27. David Kirk, "Hospitality: Essence of Eastern Christian Lifestyle," Diakonia 16/2 (1981), p. 12.

28. John B. Bennett, "The Academy and Hospitality," Cross Currents, Spring/Summer 2000, pp. 23-24.

29. Aurelie A. Hagstrom, "The Dominican Charism and Higher Education: A Personal Reflection from the Field," pp. 8o-81. 
Dominican approach to theology is dialogical; that is, it seeks to proclaim, persuade, and convince its opponents and respondents, rather than silence, defeat, and conquer them. This is one example of "intellectual hospitality" which could be practiced on our campuses in the context of meaningful dialogue, as used by St. Dominic. ${ }^{30}$

Another Dominican example would be St. Thomas Aquinas, who also employed a dialogical model in his theology. In his Summa Theologiae, he used the teachings of a Jew, Maimonides, as well as a Muslim, Averroes.3I In fact, the philosophy of the pagan, Aristotle, which was an integral element in Aquinas's project, was largely available to him only through these Jewish and Islamic scholars. In this dialogue, St. Thomas was not afraid to find truth even from people with whom he did not agree philosophically or theologically. This sort of confidence in seeking the truth wherever it may be found is based upon the conviction that truth is one, and that there can be no contradiction between the truth that flows from faith and that which comes through reason. This bold search for truth in a dialogical methodology, modeling a kind of "intellectual hospitality," is a challenge for anyone who desires to engage in theological inquiry in the Dominican tradition.

\section{Hospitality and the Advancement of the Mission of Catholic Higher Education}

How can this provocative metaphor of hospitality be employed as a framework for thinking through the issues of Catholic mission at our colleges and universities?32 To begin with, I think it can help us to frame questions of diversity on our campuses. For example, those from different religious traditions who are welcomed to our campuses are guests of our hospitality. They are the "others" who challenge us to make room, be receptive, and remain attentive to their worldviews. The sponsoring religious community of the university is the "host," whether Dominican or Jesuit, Franciscan, Benedictine, Augustinian, etc. And those students, faculty, administrators, or staff from diverse religious traditions, who are part of the campus community, are the "guests." The definition of these roles is important, because it allows the hosts and the guests to be true to their own religious identities in an atmosphere of mutual acceptance and welcome without compromising into a bland relativism that diminishes the uniqueness and gifts of these identities.

In hospitality, it is important to remember who is the host-who set the table, in other words. The "table is set" in a certain way according to the sponsoring religious community. The guests are welcomed to the table, but the hosts are not expected to change the table setting simply because the guests are not used to these habits and

30. Simon Tugwell, ed., Jordan of Saxony: On the Beginnings of the Order of Preachers (Dublin: Dominican Publications, 1982), pp. 4-5. See also Bede Jarrett, Life of St. Dominic (Westminster, Md.: Newman Bookshop, 1947), pp. 17-18.

31. St. Thomas Aquinas, Summa Theologiae.

32. See Aurelie A. Hagstrom, "Christian Hospitality in the Intellectual Community," in Christianity and the Soul of the University, Douglas Henry and Michael Beaty, eds. (Grand Rapids: Baker Academic, 2006), pp. 119-131. customs. The religious identity, praxis, and worship of the host are not abandoned in the interchange of hospitality. Indeed, it is only the clear identity of the host that makes the guest feel secure and welcome. If the customs or habits of the table manners of the host are unclear or ambiguous, the guest feels awkward and unsure of how to behave or react. The Catholic, or Dominican, Jesuit, Franciscan, Benedictine, Augustinian, etc., identity of the university has to be clear to others who are welcomed as guests.

This metaphor of hospitality could also apply to questions of academic freedom. One thing that happens as a result of table fellowship is conversation. The host and the guest tell their stories. This interchange is encouraged by the experience of hospitality. The atmosphere of invitation, welcome, and communio of persons is precisely what can give rise to sharing and storytelling. It also gives rise to healthy debate and disputation. Since there is a level of trust between the host and guest, both are empowered to tell their story of how they understand the world. Table fellowship is the context where hostility can be transformed to hospitality and the stranger is welcomed as guest and, eventually, friend.

As host, the sponsoring religious community "tells its story" in a variety of ways across campus life. The mission statement, curriculum, student life policies, and faculty hiring procedures are but a few examples of how this story is told. They are the "narrative" of the host, if you will. And when the guests hear this story, they cannot then ask the host to change it. Likewise, the guests have a right to their stories, without the host asking them to change their perceptions, convictions, and values. Academic freedom should flourish in this context, as long as it is understood what the hosts' narrative is and how the whole life of the campus is then fundamentally oriented to this story, without apology.

The metaphor of hospitality, therefore, is helpful in framing the questions of diversity and academic freedom on the campuses of Catholic colleges and universities. By using this model of campus life, our institutions can create an atmosphere that is rigorously intellectual, academically free, and even hospitable to the conflict and tension that is part and parcel of the educational enterprise. Hospitality makes room for the gifts and burdens of others and provides stable community in a fragmented world. Hospitality can manifest itself in friendship and truth. And this emphasis on truth is important because it helps counter a tendency toward a mere tolerance of other beliefs and ideas that can slip into a well-intentioned, but sloppy, relativism and indifference which ignores claims of Christian revelation and objectivity.

\section{Hospitality vs. Tolerance}

Here, perhaps, it is important to include a word about tolerance versus hospitality. I think it is vitally important to remember that mere "tolerance" is not true dialogue. Hospitality is much more engaging, risky, and costly than the mere tolerance of diversity is. Mere tolerance cannot sustain our communities or our conversations in moments of crisis or deep disagreement. Hospitality, by contrast, is incarnational. It does not exist as a disembodied attitude toward others, like tolerance, but is instead a practice of bringing strangers and guests into a ritual of peaceful engagement. Hospitality takes the identity, story, and tradition of the guest seriously as a foundation for table fellowship and meaningful dialogue. 
As John C. Haughey has stated:

[A] Catholic university inevitably houses many worldviews. It can do this in several ways. One is simply to make room for those who hold these plural worldviews. This is a negligent, or, at best, a merely tolerant hospitality. A second way a university can house plural worldviews is by hearing them, taking them seriously, engaging them. This second form of hospitality can lead to a real growth in understanding on the part of both hosts and guests. ${ }^{33}$

Mere tolerance cannot sustain our communities or our conversations in moments of crisis or deep disagreement. Hospitality, by contrast, is incarnational. It does not exist as a disembodied attitude toward others, like tolerance, but is instead a practice of bringing strangers and guests into a ritual of peaceful engagement.

Authentic dialogue, and not mere tolerance, is fundamental in any attempt to extend hospitality, because dialogue is a basic form of "engagement of the other." The hospitable attitudes such as attention to the other, receptivity, and openness are typically expressed in dialogue and conversation. The hospitable creation of a free space most often begins in the experience of dialogue.

Hospitality involves a way of thinking without the presumption of knowing beforehand what is in the mind of the other; dialogue with the other is essential. I must let the other tell me who he or she is. Hospitality decenters our perspective; my story counts but so does the story of the other. . . To welcome the other means to let the other tell his or her story. So listening becomes a basic attitude of hospitality. Being hospitable means being genuinely open to the other, interested in sharing, learning, and receptive to the learning the other might possess. ${ }^{34}$

\section{Conclusion}

Hospitality, as a framework and a practice, has the potential to integrate Catholic identity into the various dimensions of campus life. In my opinion, the biblical theology of hospitality presents fruitful implications for Catholic colleges and universities and informs aspects of the academy as diverse as curriculum, academic freedom, faculty hiring, student life policies, campus ministry, and administration.

33. John C. Haughey, S.J., Where Is Knowing Going? The Horizons of the Knowing Subject (Washington, D.C.: Georgetown University Press, 2009), p. 37.

34. Lucien Richard, p. 12
Perhaps in this current phase of implementation of Ex Corde Ecclesiae, Catholic institutions could benefit from engaging this provocative and multi-layered reality of hospitality. Now that mission statements have been revised and vice presidents of mission have been hired, the "table is set" for a new initiative. Hospitality, as witnessed in Scripture, can be a space for divine encounter as the "other" offers a message that deepens our own understanding of ourselves. This interchange, it seems to me, has the potential to bring about real transformation and renewal to our campuses. 


\section{Bibliography}

Bennett, John B., "The Academy and Hospitality," Cross Currents, Spring/Summer 2000, pp. 23-35

Boersma, Hans, Violence, Hospitality, and the Cross, Reappropriating the Atonement Tradition (Grand Rapids: Baker Academic, 2004)

Brueggemann, Walter, The Land: Place as Gift, Promise, and Challenge in Biblical Faith (Philadelphia: Fortress Press, 1977)

Byrne, Brendan, The Hospitality of God (Collegeville, Minn.: Liturgical Press, 2000)

Elliott, John H., A Home for the Homeless: A Sociological Analysis of I Peter (Philadelphia: Fortress Press, I98I)

Emminghaus, Johannes, The Eucharist: Essence, Form, Celebration (Collegeville, Minn.: Liturgical Press, I978)

Feeley-Harnack, Gillian, The Lord's Table: The Meaning of Food in Early Judaism and Christianity (Washington, D.C.: Smithsonian Press, 1994)

Gafney, Leo, "Sharing the Meal," America, May I7, I997, pp. 20-2I

Hagstrom, Aurelie, "Advent, Mary, and Hospitality: Making Room for the Lord," Ministry Q Liturgy, Volume 38, Number 7, September 20II

Hagstrom, Aurelie, "Transformation: A Catholic Agenda in the Dominican Tradition, The Biblical Notion of Hospitality as the Model of a Catholic University," Dominican Studies Journal, Centennial Edition, Ohio Dominican University, Spring 2010

Hagstrom, Aurelie, "The Spirituality of Hospitality and Dialogue in the Church," Ministry a Liturgy, Volume 37, Number 2, March 2010

Hagstrom, Aurelie, "The Dominican Charism and Higher Education: A Personal Reflection from the Field," Journal of Catholic Higher Education, Volume 29, Number I, Winter 2010

Hagstrom, Aurelie, "Christian Hospitality in the Intellectual Community," in Christianity and the Soul of the University, Douglas Henry and Michael Beaty, eds. (Grand Rapids: Baker Academic, 2006), pp. II9-I3I

Hagstrom, Aurelie, "Table Manners," National Catholic Register, March I9, I995

Halverson, Delia, The Gift of Hospitality: In Church, in the Home, in All of Life (St. Louis: Chalice Press, 1999)

Haughey, John C., Where Is Knowing Going? The Horizons of the Knowing Subject (Washington, D.C.: Georgetown University Press, 2009)

Hellwig, Monika, Guests of God: Stewards of Divine Creation (New York: Paulist Press, I999)

Hellwig, Monika, The Eucharist (Kansas City, Mo.: Sheed and Ward, I992),

Homan, Daniel, Lonni Collins Pratt, Radical Hospitality (Brewster, Mass.: Paraclete Press, 2002)

Just, Arthur, The Ongoing Feast: Table Fellowship and Eschatology at Emmaus (Collegeville,

Minn.: Liturgical Press, I993)

Kirk, David, "Hospitality: Essence of Eastern Christian Lifestyle," Diakonia I6/2 (I981), pp. IO4-II7

Koenig, John, New Testament Hospitality (Philadelphia: Fortress Press, 1985)

LaVerdiere, Eugene, Dining in the Kingdom of God (Chicago: Liturgical Training Publications, 1994)

Malherbe, Abraham, Social Aspects of Early Christianity, and edition (Philadelphia: Fortress Press, 1983)

Newman, Beth, Untamed Hospitality: Welcoming God and Other Strangers (Grand Rapids: Brazos Press, 2007)

Newman, Elizabeth, "Hospitality and Christian Higher Education," Christian Scholar's Review 33 (2003), pp. 75-93

Nouwen, Henri, "Hospitality," Monastic Studies, Number Io: Easter I974

Ogletree, Thomas, Hospitality to the Stranger (Philadelphia: Fortress Press, I985)

Palmer, Parker, The Company of Strangers: Christianity and the Renewal of America's Public Life (New York: Crossroad, I98I)

Pineda, Ana Maria, "Hospitality," in Practicing Our Faith, Dorothy C. Bass, ed. (San Francisco: Jossey-Bass Publishers, I997), pp. 29-42

Pohl, Christine, Making Room: Recovering Hospitality as a Christian Tradition (Grand Rapids: Eerdmann's Publishing Company, 1999)

Pope John Paul II, Novo Millennio Ineunte, Apostolic Letter, January 6, 200

Reynolds, Thomas E., Vulnerable Communion: A Theology of Disability and Hospitality (Grand Rapids: Brazos Press, 2008)

Richard, Lucien, Living the Hospitality of God (New York: Paulist Press, 2000)

Smith, D. E., "Table Fellowship as a Literary Motif in the Gospel of Luke," Journal of Biblical Literature, 106 (1987), pp. 613-638

Sutherland, Arthur, I Was A Stranger: A Christian Theology of Hospitality (Nashville: Abingdon Press, 2006)

Yong, Amos, Hospitality a the Other: Pentecost, Christian Practices, and the Neighbor (Maryknoll, N.Y.: Orbis Books, 2008) 